EDUKIDS: Jurnal Pertumbuhan, Perkembangan, dan Pendidikan Anak Usia Dini

Jln. Dr. Setiabudhi No. 229 Kota Bandung 40154. e-mail: edukid@ upi.edu website: http://ejournal.upi.edu/index.php/edukid

\title{
UPAYA ORANG TUA UNTUK MENCEGAH KETERGANTUNGAN ANAK TERHADAP PENGGUNAAN GADGET
}

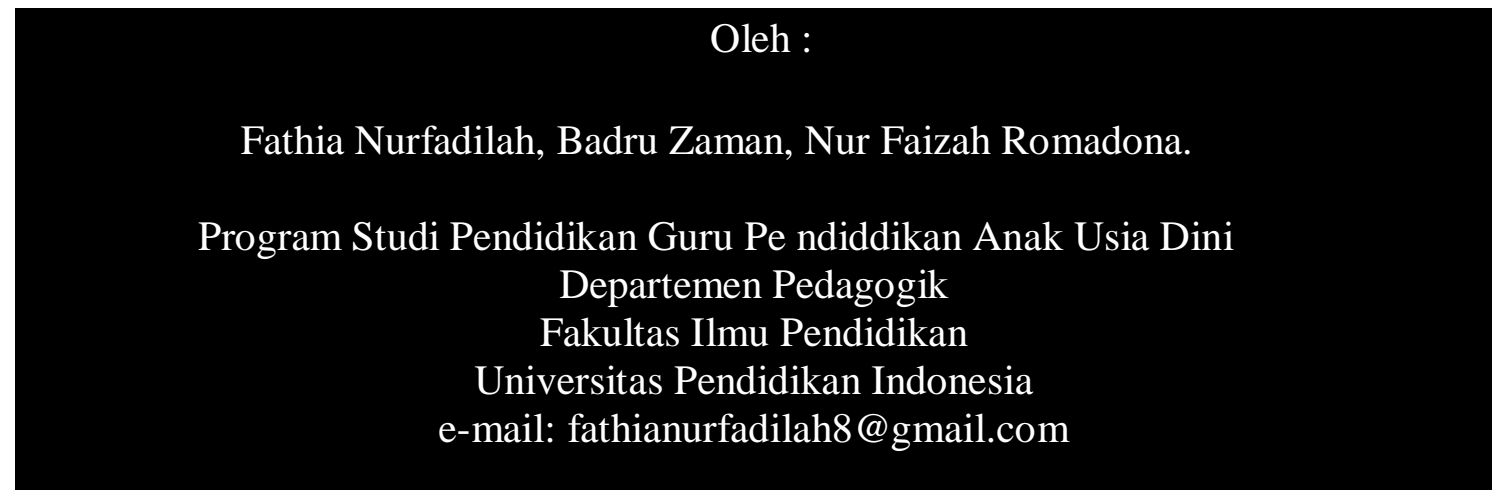

\begin{abstract}
Abstrak : Penelitian ini berdasarkan temuan, bahwa saat ini mulai marak penggunaan gadget oleh anak usia dini yang tidak banyak dibatasi waktunya oleh orang tua sehingga menimbulkan ketergantungan. Adapun tujuan penelitian ini untuk mengetahui pandangan dan upaya orang tua dalam mencegah ketergantungan anak terhadap penggunaan gadget. Metode yang digunakan dalam penelitian ini adalah studi kasus. Teknik pengumpulan data menggunakan wawancara. Partisipan dalam penelitian ini sebanyak 2 orang ibu dari anak usia dini yang sering menggunakan gadget. Hasil penelitian menunjukan bahwa pandangan orang tua terhadap penggunaan gadget untuk anak terdapat pendapat positif dan pendapat negatif. Adapun upaya orang tua untuk mencegah ketergantungan anak terhadap penggunaan gadget meliputi: 1) Bersikap tegas dengan melarang anak apabila sudah bermain terlalu lama; 2) tidak mencontohkan menggunakan gadget di depan anak sehingga harus bersembunyi saat menggunakan gadget; 3) mengajak anak untuk bermain diluar dan berinteraksi dengan tetangga dan mengalihkan perhatiannya dengan kegiatan lain; 4) memasukan anak kesekolah agar mengurangi frekuensi anak menggunakan gadget; 5) memberhentikan akses wifi dirumah. Adapun pihak yang membantu dalam pencegahan yaitu dari pihak keluarga yang membantu mengingatkan. Direkomendasikan bagi peneliti selanjutnya agar dapat mengembangkan penelitian lanjutan dengan memperdalam ketergantungan gadget pada anak usia dini ini, dengan desain penelitian lain atau menggunakan sampel yang lebih banyak.
\end{abstract}

\section{Kata Kunci: ketergantungan gadget, orang tua}




\begin{abstract}
The research is based on the findings, that at this time many gadgets are being used by early childhood children which are not limited in time by parents, causing dependence.The purpose of this study is to determine the views and efforts of parents in preventing children's dependence on the use of gadgets. The method used in this research is a case study. Data collection techniques using interviews. Participants in this study were 2 mothers of children who often use gadgets. The results showed that parents' views on the use of gadgets for children contained positive opinions and negative opinions. The efforts of parents to prevent children's dependence on the use of gadgets include: 1) Be assertive by banning children if they have been playing for too long; 2) do not exemplify using gadgets in front of children so they must hide when using gadgets; 3) invites children to play outside and interact with neighbors and distract them with other activities; 4) include children in school to reduce the frequency of children using gadgets; 5) stop wifi access at home.As for those who help in prevention, that is from the family who helps remind.It is recommended for further researchers to be able to develop further research by deepening the dependence of the gadget on early childhood, with other research designs or using more samples.
\end{abstract}

Keyword: gadget dependency, parents.

\section{PENDAHULUAN}

Perkembangan teknologi
semakin berkembang dengan pesat
sesuai dengan perkembangan
zaman.Teknologi muncul dengan
berbagai macam jenis dan fitur.
Teknologi selalu baru dari hari ke hari.
Kebutuhan terhadap teknologi
merupakan salah satu kebutuhan
penting saat ini, hal ini disebabkan
karena teknologi sangat dibutuhkan
untuk memenuhi berbagai kebutuhan
hidup manusia (Pebriana, 2017). Salah
satu produk teknologi yang sangat
dibutuhkan saat ini adalah aplikasi
teknologi informasi. Manfaat yang
dapat diberikan oleh aplikasi teknologi
informasi adalah mendapatkan
informasi untuk kehidupan pribadi
seperti informasi tentang kesehatan,
hobi, rekreasi, dan rohani. Selain itu
untuk profesi seperti sains, teknologi,
perdagangan, berita bisnis, dan asosiasi
profesi. Sarana kerjasama antara
pribadi atau kelompok yang satu
dengan pribadi atau kelompok yang
lainnya tanpa mengenal batas jarak dan
waktu, negara, ras, kelas ekonomi,

ideologi atau faktor lainnya yang dapat menghambat bertukar pikiran (Wardiana, 2014).

Salah satu produk aplikasi teknologi informasi yang terkait dengan pemenuhan kebutuhan yang paling berkembang pada saat ini adalah gadget. Pada era globalisasi seperti saat ini, kebutuhan seseorang untuk melakukan interaksi sosial khususnya untuk berkomunikasi satu dengan lainnya tidak-lah susah. Hanya dengan menggunakan gadgetseseorang dapat berinteraksi satu dengan orang lain. Gadget sendiri dapat berupa komputer atau laptop, tablet $P C$, dan juga telepon seluler atau smartphone.Gadget pada era globalisasi sangatlah gampang dijumpai, sebab hampir semua kalangan masyarakat memiliki gadget. Pasalnya gadget tidak hanya beredar di kalangan remaja (usia 12-21 tahun) dan dewasa atau lanjut usia (usia 60 tahun keatas), tetapi juga beredar di kalangan anak-anak (usia 7-11 tahun) dan ironisnya lagi gadget bukan barang asing untuk anak (usia 3-6) tahun yang 
seharusnya belum layak menggunakan gadget (Novitasari, 2016).

Penggunaan gadget bagi anak usia dini bagai dua mata pisau. Di satu sisi memberikan banyak manfaat bagi perkembangan anak, namun di sisi lain juga memberikan dampak yang berbahaya bagi pengembangan karakternya. Pendiri New ParentAcademy, Akbar (2015), memaparkan gadget memiliki beberapa manfaat yakni dapat menunjang pengetahuan serta mempersiapkan anak menghadapi dunia digital. Dia menjelaskan, pengetahuan bisa diperoleh melalui beragam aplikasi edukatif yang bisa diunduhgadgettersebut. Aplikasi semisal menebak warna bisa melatih kemampuan anak dalam mengenali jenis-jenis warna di sekitarnya. Selain itu, gadget juga dapat melatih kemampuan berbahasa asing anak karena biasanya aplikasi maupun program yang tertera di gadget menggunakan bahasa asing.

Pengenalan gadget pada anak usia dini sangat penting,karena dapat membantu menstimulasi imajinasi, membantu memperbaiki kemampuan mendengar, mempelajari suara-suara dan bicara, serta dapat membantu daya pikir strategi anak, namun tetap pada pengawasan orangtua. Sebagian besar orang menganggap bahwa dengan memberikan gadgetpada anak akan lebih mudah orang tua melakukan pekerjaan mereka dari pada terus diganggu oleh si anak, pada sisi lain lagi orangtua atau guru berpendapat bahwa dengan memberikan gadget pada anak sejak dini anak akan lebih familiar dengan teknologi sehingga membuat mereka dapat memiliki wawasan dan ilmu pengetahuan yang lebih cepat dan luas.

$\begin{array}{rrr}\text { Namun, } & \begin{array}{r}\text { gadget } \\ \text { sejumlah }\end{array} & \begin{array}{r}\text { juga } \\ \text { dampak }\end{array}\end{array}$

negatif antara lain dapat menghambat perkembangan motorik anak, menghambat perkembangan bahasa dan sosial anak, menimbulkan masalah perilaku, serta menimbulkan masalah kesehatan fisik. Anak usia dini masih dalam tahap perkembangan motorik yang mengharuskannya banyak bergerak. Disisi lain penggunaan gadget yang berlebihan akan membuat anak diam terlalu lama sehingga perkembangan kesehatannya akan terganggudananak akan mengalami obesitas. Bahkan tak hanya motoriknya, kemampuan berbahasa dan bersosial anak juga akan terhambat karena anak tidak banyak berinteraksi dengan orang lain.Selanjutnya adalah dapat menurunkan daya konsentrasi dan meningkatkan ketergantungan anak untuk dapat mengerjakan berbagai hal yang semestinya dapat mereka lakukan sendiri. Lebih lanjut, semakin terbukanya akses internet dalam gadget yang menampilkan segala hal yang semestinya belum waktunya dilihat oleh anak-anak mengandung akibat negatif yang membahayakan anak karena banyaknya fitur atau aplikasi yang tidak sesuai dengan usia anak. Dampak negatif terbesar bagi anak adalah ketika anak ketergantungangadget.

Ketergantungangadgetakan

membuatanak lupa bersosialisasi dengan lingkungan sekitarnya yang berdampak psikologis terutama krisis percaya diri pada anak, menghilangkan ketertarikan pada aktivitas bermain atau melakukan kegiatan lain. Ini yang akan membuat anak lebih bersifat menyendiri. Banyak anak yang lebih memilih bermain gadget ketimbang bermain dengan teman untuk bermain sekedar bermain bola dilapangan .

Ketika anak telah kecanduan gadgetakan membuat anak merasa gelisah jika dipisahkan dengan gadget tersebut. Sebagian besar waktu mereka habis untuk bermain gadget. Akibatnya 
tidak hanya kurangnya kedekatan antara orang tua anak-anak juga cenderung menjadi introvert. Selain itu juga dapat mempengaruhi perkembangan otak anak. PFC (Pe Frontal Cortex) adalah bagian di dalam otak yang mengontrol emosi, kontrol diri, tanggung jawab dan nilai moral lainnya. Anak yang kecanduan teknologi, otaknya akan memproduksi hormon dopamine secara berlebihan yang mengakibatkan fungsi PFC terganggu (Hastuti, 2012).

Terkait dengan hal tersebut peran orang tua menjadi sangat penting dalam mendampingi anak. Orang tua harus mengetahui batasan kapan anak diperbolehkan untuk menggunakan gadget dan berapa lama durasianak boleh menggunakan gadget. Menurut Kementerian Pemberdayaan Perempuan dan Perlindungan Anak (PPPA) Republik Indonesia menyebutkan penggunaan gadget adalah hak anak, namun usia ideal anak dapat mengakses gadget adalah saat menginjak usia 13 tahun.

\section{METODE PENELITIAN}

Desain penelitian yang digunakan dalam penelitian ini adalah menggunakan jenis penelitian Studi Kasus. Menurut Creswell (2010) merupakan strategi penelitian di mana di dalamnya peneliti menyelidiki secara cermat suatu program, peristiwa, aktivitas, proses, atau sekelompok individu.Subjek dalam penelitian ini yaitu dua orang tua yang berbeda yang bertempat tingga di Tasikmalaya. Metode pengumpulan data menggunakan metode wawancara.

\section{HASIL DAN PEMBAHASAN}

Upaya orang tua dalam melakukan pencegahan terhadap penggunaan gadgetpada anak usia dini ini merupakan hasil kajian peneliti terkait dengan upaya yang orang tua untuk mencegah ketergantungan Anak terhadap penggunaan gadget. Peneliti ingin memaparkan bahwasannya peran orang tua sangatlah berpengaruh dalam mencegah agar anak tidak ketergantungan gadget, sehingga peneliti ingin memberikan gambaran terkait dengan upaya orang tua dalam melakukan pencegahan terhadap penggunaan gadgetpada anak usia dini.

Pada bagian ini akan dibahas mengenai temuan hasil penelitian yang telah dikemukakam sebelumnya, mengenai upaya orang tua untuk mencegah ketergantungan anak terhadap penggunaan gadget. Meliputi 1) pandangan orang tua terhadap penggunaan gadget pada anak, 2) pandangan orang tua tentang dampak penggunaan gadget untuk anak, 3) upaya yang telah dilakukan orang tua untuk mencegah ketergantungan anak terhadap penggunaan gadget, 4) kendala dalam mencegah ketergantungan anak terhadap gadget, 5) pihak yang membantu dalam mencegah ketergantungan anak terhadap penggunaan gadget.

\section{Pandangan orang tua terhadap penggunaan gadget pada anak.}

Orang tua memiliki pandangan yang berbeda beda. Orang tua berpandangan bahwa gadget tidak seharusnya digunakan oleh anak usia dini karena banyak dampak negatif yang beresiko untuk kesehatan anak. Psikolog Prima (2015) mengatakan, anak usia dini masih dalam tahap perkembangan motorik yang mengharuskannya banyak bergerak. Disisi lain penggunaan gadget yang berlebihan akan membuat anak diam terlalu lama sehingga perkembangan kesehatannya akan terganggudananak akan mengalami obesitas. Bahkan tak hanya motoriknya, kemampuan berbahasa dan bersosial anak juga akan 
terhambat karena anak tidak banyak berinteraksi dengan orang lain.

Namun, orang tua juga berpandangan bahwa gadget boleh digunakan oleh anak dengan tujuan hanya untuk sekedar rekreasi dan untuk hiburan sementara dan tidak untuk dimainkan berlama-lama. Sebagai orang tua seharusnya bisa memantau lama pemakaian gadget untuk anak, misalkan satu jam sehari anak hanya boleh memakai gadget.Membatasi penggunaan gadget sesuai usia anak adalah hal yang penting untuk perkembangan mental dan intelektual anak. Karena anak pun masih perlu bermain diluar rumah untuk melatih motoriknya. Meski diakui bahwa gadget juga memiliki konten yang baik dan bagus untuk perkembangan anak. Namun, jika tidak selektif dan dibatasi, screentime yang berlebihan bisa berdampak buruk pada anak. Sebagai orang tua, kita harus berani tegas dalam menetapkan aturan terkait memberikan gadget pada anak. Meski anak mengeluh ini itu, Anda harus tetap kuat menerapkan aturan itu.

\section{Pandangan orang tua terhadap dampak penggunaan gadget pada anak}

Penggunaan gadget pada anakbagai dua mata pisau. Di satu sisi memberikan banyak manfaat bagi perkembangan anak, namun di sisi lain juga memberikan dampak yang berbahaya bagi pengembangan karakternya. Salah satu dampak positif gadget pada anak yaitu dapat dilihat dari konten yang di gunakan oleh anak. Sebagai orang tua, memang perlu mewaspadai game komputer atau internet karena banyak dari game tersebut yang mengandung unsur yang tidak sesuai untuk anak. Maka pilihlah permainan yang bersifat edukatif ( Wulansari, 2018, hlm.54).
Secara teori menurut Pendiri New Parent Academy, Akbar (2015), salah satu dampak positif dari gadget adalah dapat menunjang pengetahuan serta mempersiapkan anak menghadapi dunia digital. Dia menjelaskan, pengetahuan bisa diperoleh melalui beragam aplikasi edukatif yang bisa diunduh gadget tersebut. Aplikasi semisal menebak warna bisa melatih kemampuan anak dalam mengenali jenis-jenis warna di sekitarnya. Selain itu, gadget juga dapat melatih kemampuan berbahasa asing anak karena biasanya aplikasi maupun program yang tertera di gadget menggunakan bahasa asing. Sesuai dengan salah satu penelitian yang dilakukan Sari dan Mitsalia (2016), pengaruh penggunaan gadget terhadap anak usia pra sekolah cenderung ke arah yang positif yaitu sebanyak $71 \%$. Hal ini disebabkan karena dari gadget anak dapat mengikuti pembelajaran seperti menghafal al-qur'an, dan mengetahui kosa kata bahasa inggris sehingga anak merasa terbantu dalam membaca ataupun menghafal. Gadget juga dapat dijadikan sarana hiburan bagi anak.

Namun adapun dampak negatif gadget pada anak radiasi dari gadget tersebut akan menyebabkan tangan menjadi cepat panas bila kita terlalu lama menggunakan gadget. Jika anakanak sudah berpegangan dengan barang yang memiliki radiasi yang tinggi akan menyebabkan anak menjadi ketergantungan. Bila hal ini dibiarkan secara terus menerus, syaraf otak yang bekerja produktif sebelumnya akan menjadi mati dan fungsi otak menjadi sangat lambat dikarenakan kertergantungan gadget tersebut.Mercada-Deane, dari American Academy of Pediatrics (dalam Wulansari, 2017, hlm.20) menjelaskan bahwa hal yang dikhawatirkan adalah efek dari pancaran radiasi pada anak. Tengkorak 
anak juga lebih tipis dan bisa menyerap radiasi ponsel lebih banyak.

$$
\text { Gadget juga membentuk }
$$
kebiasaan yang cenderung hanya menyimak tanpa ada tindakan fisik secara nyata dan memicu terjadinyasifat malas. Awalnya malas bergerak, lama-lama menjadi malas dalam banyak hal, seperti malas makan, malas mandi, malas belajar, malas bermain, malas keluar rumah, malas bermain bersama teman, dan sebagainya. Secara teori menurut psikolog Prima (2015) anak usia dini masih dalam tahap perkembangan motorik yang mengharuskannya banyak bergerak. Disisi lain penggunaan gadget yang berlebihan akan membuat anak diam terlalu lama sehingga perkembangan kesehatannya akan terganggu dan anak akan mengalami obesitas. Bahkan tak hanya motoriknya, kemampuan berbahasa dan bersosial anak juga akan terhambat karena anak tidak banyak berinteraksi dengan orang lain.

\section{Upaya yang telah dilakukan orang tua untuk mencegah ketergantungan anak terhadap penggunaan gadget}

Setiap orang tua memiliki
caranya masing masing dalam
berupaya mencegah ketergantungan
gadget. Bentuk-bentuk pencegahan
yang dilakukan orang tua terhadap
anak dilakukan dengan cara yang
mudah diterima oleh anak. Salah satu
hal yang dapat dilakukan olehh orang
tua yaitu Bersikap tegas dengan
melarang anak apabila sudah bermain
terlalu lama kemudian langsung
mengambil ponselnya sehingga anak
terhenti bermain meskipun anak
menolak atau menangis. Sebagai orang
tua harus bersikap tegas terhadap anak.
Orang tua juga perlu mengontrol
berapa lama anak diperbolehkan
menggunakan gadget agar tidak

berpengaruh pada kesehatan mental dan fisiknya. Untuk menjaga kesehatan fisik menurut Pakar Pediatric dari USA, sebaiknya tidak membiasakan anak menonton layar monitor lebih dari 9 menit setiap hari karena organ visual anak masih lentur dan sistem biopsinya hanya tahan selama itu. Jika lebih dari itu, dikhawatirkan akan mengganggu sistem penglihatannya.

Selanjutnya, Tidak mencontohkan menggunakan ponsel di depan anak sehingga harus bersembunyi saat menggunakan ponsel. Warisyah (2015) menyebutkan bahwa Modellingyang tepat dari orangtua sangat dibutuhkan bagi penggunaan gadgetpada anak prasekolah.Salah satu teori yang dikemukan oleh John Locke bahwa modelling yang baik sangat mempengaruhi perilaku anak, yakni bahwa anak-anak mempelajari apa yang mereka lihat dari lingkungan sekitarnya. Karena sebaik-baiknya orang tua adalah yang dapat mencontohkan baik kepada anak.sebagai orang tua sebisa mungkin kita harus bisa menjadi contoh yang baik untuk anak-anak. Sesuai dengan pendapat Hurlock (1978) bahwa orang yang paling penting bagi anak adalah orang tua, guru, dan teman sebaya (peergroup). Melalui merekalah anak mengenal sesuatu positif dan negatif. Anak mulai belajar dan meniru apa yang dilihatnya, terutama adalah perilaku orang tua sebab keluarga merupakan salah satu pembentuk karakter anak.

Orang tua mempunyai pengaruh sangat besar bagi perkembangan moral anak, karena anak akan memandang orang tua sebagai sosok model yang paling sempurna untuk ditiru. Anak akan meniru apapun yang dilakukan oleh orang tuanya. Menurut Gunarsa (dalam Wijanarko, 2016, hlm. 49) pola asuh orang tua pada dasarnya adalah 
sikap, cara dan kebiasaan orang tua yang diterapkan untuk mengasuh, memelihara dan membesarkan anak dilingkungan keluarga. Karena selain pola asuh, penting juga bagaimana orang tua dan anak berinteraksi.

Peran orang tua terhadap anaknya harus selalu dilakukan. Mengontrol setiap konten yang dimainkan oleh anak merupakan salah satu cara yang efektif. Selain itu, lebih sering mengajak anak untuk berdiskusi, tanya jawab dan bermain bersama dengan anak akan mengembangkan daya imajinasi dan kreatifitasnya.

\section{Kendala dalam mencegah ketergantungan anak terhadap gadget}

Kendala yang dihadapi orang tua mungkin saja anak belum mengerti apa yang di katakan oleh orang tua dalam pencegahan ketergantungan gadget. Namun pada dasarnya Gadget telah mengubah pola pengasuhan anak dan mengubah perilaku anak. Banyak perilaku anak yang mengalami penyimpangan dan dilaporkan bahwa itu ada hubungannya dengan penggunaan gadget. Dr Jenny Radensy (dalam Wijanarko, 20 mengatakan bahwa anak-anak tidak bisa belajar dari video ataupun dunia maya sebaik berinteraksi dengan kehidupan nyata dan lingkungan sekitarnya. Anak-anak sesungguhnya belajar melalui sentuhan dan pengalaman yang mereka jumpai setiap harinya.

Ketika anak telah kecanduan gadgetakan membuat anak merasa gelisah jika dipisahkan dengan gadget tersebut. Sebagian besar waktu mereka habis untuk bermain gadget. Akibatnya tidak hanya kurangnya kedekatan antara orang tua anak-anak juga cenderung menjadi introvert. Selain itu juga dapat mempengaruhi perkembangan otak anak. PFC (Pe Frontal Cortex) adalah bagian di dalam otak yang mengontrol emosi, kontrol diri, tanggung jawab dan nilai moral lainnya. Anak yang kecanduan teknologi, otaknya akan memproduksi hormon dopamine secara berlebihan yang mengakibatkan fungsi PFC terganggu (Hastuti, 2012). Maka dari itu butuhnya peran orang tua menjadi sangat penting dalam mendampingi anak. Orang tua harus mengetahui batasan kapan anak diperbolehkan untuk menggunakan gadget dan berapa lama durasianak boleh menggunakan gadget.

\section{Pihak lain yang membantu dalam mencegah ketergantungan anak terhadap gadget.}

Pihak yang membantu dalam mencegah ketergantungan gadget diantaranya ada pihak keluarga dan juga sekolah. Pihak keluarga yang dapat membantu selain ibu adalah ayah. Ayah merupakan pendisiplin yang tegas. Menurut penelitian yang dilakukan Pruett (dalam Wijanarko, 2016, hlm. 137) anak punya kekuatan khusus ketika ayahnya terlibat aktif dalam keseharian mereka. Terlibat aktif atau ikut berperan dalam arti bukan berperan tunggal, tetapi bersama-sama istri mendidik anak. Keterlibatan ayah dalam menerapkan disiplin yang cukup tinggi akan mengurangi kecenderungan anak untuk berperilaku menyimpang terutama pada masa sekolahnya.

Adapun jika anak sudah sekolah, pihak sekolah membantu dalam mencegah ketergantungan gadget diantaranya dengan cara penyuluhan kepada anak agar anak tidak terlalu sering menggunakan gadget dan dilarang membawa gadget ke sekolah. Pihak sekolah membantu dengan memberikan larangan bagi anak untuk membawa gadget ke sekolah. Namun disisi lain, sekolah memfasilitasi tablet dalam rangka 
pengenalan Informasi dan Teknologi pada anak di sekolah. Dengan demikian karena jumlah anak dikelas banyak maka tidak ada anak yang memonopoli penggunaan gadget, jadi anak tetap terbatasi dalam penggunaan gadget karena adanya aturan larangan dari sekolah untuk menggunakan gadget terlalu lama.

Bahkan di negara Swedia sudah ada larangan untuk membawa gadget ke sekolah. Penggunaan gadget di sekolah dianggap telah mengganggu kesehatan dan hubungan sosial anak. Tiga ahli kesehatan di negara tersebut menilai meningkatnya ketergantungan anak-anak pada media digital dianggap sudah mengarah pada sikap yang berbeda yang menyebabkan perkembangan otak anak dapat terpengaruh secara negatif akibat penggunaan gadget (Yulianingsih, 2018).

\section{KESIMPULAN}

Ketergantungan gadget pada anak usia dinimerupakan kondisi dimana anak menggunakan gadget secara terus menerus lebih dari 2 (dua) jam. Anak akan melakukan protes bahkan jika tidak diberikan gadget bahkan anak tidak dapat melewatkan waktu sehari pun tanpa gadget. Dalam upaya mencegah ketergantungan anak terhadap penggunaan gadget, orang tuaperlu memiliki pemahaman, sehingga orang tua dapat memberikan pencegahan yangtepat untuk melakukan pembiasaan-pembiasaan bagi anak-anaknya dalam mengurangi penggunaan gadget secara terusmenerus. Menurut pemahaman orangtua,gadget memiliki manfaat positif dan dampak negatif bagi anak. Manfaat positif diantaranya anak dapat belajar dari berbagai konten-konten yang sesuai. Adapun dampak negatif gadget bagi anak salah satunya anak akan kurang aktif dalam bersosialisasi maupun kurang aktif secara fisik.
Bentuk-bentuk pemberian pencegahan yang dapat dilakukan oleh orang tua, seperti memberi arahan, memberi pengertian, memberi nasehat dan lainsebagainya. Salah satu upaya yang dapat dilakukan orang tua yaitu bermain bersama sang anak.. Hal tersebut dapat membuat anak merasa nyaman tanpa harus menggunakan gadget .Selain itu, orang tua dapat berupaya mengarahkan anak untuk dapat berinisiatif melakukan interaksi dengan tetangga atau dengan teman sebayanya agar anak dapat bermain dengan teman sebaya nya ketika sedang melakukan kegiatan yang lain. Upaya lainnya yang dapat dilakukan orang tua seperti memberi aturan ketika anak tetap ingin menggunakan gadget, seperti konten apa saya yang boleh digunakan, memberi batas waktu bermain misalkan hanya boleh menggunakan gadget 15 menit perhari, dan juga tetap dalam pengawasan orang tua. Orang tua sangat berperan penting dalam mengantisipasi ketergantungan anak terhadap penggunaan gadget, orang tua perlu menjadi teladan yang baik bagi anak. Jika anak mendapatkan batasan waktu untuk menggunakan gadget begitupun dengan orang tua, tidak menggunakan gadget didepan anak, agar dapat menjadikan contoh yang baik secara adil.

\section{DAFTAR PUSTAKA}

Hastuti. (2012). Psikolog

Perkembangan Anak. Yogyakarta: Tugu Publisher.

Pebriana, P.H. (2017). Analisis Penggunaan Gadget terhadap Kemampuan Interaksi Sosialpada Anak Usia Dini. Jurnal Obsesi, Vol 1 (No.1), hal 1-11.

Wijanarko, J \& Setiawati, E. (2016). Pengaruh Gadget pada Perilaku 
dan Kemampuan Anak Menjadi Orang Tua Bijak di Era Digital. Jakarta : Keluarga Indonesia Bahagia.

Wardiana, P. A., Wiarta, I. W., \& Zulaikha, S. (2014). Hubungan antara Adversity Quotient (Aq) dan Minat Belajar dengan Prestasi Belajar Matematika pada Siswa Kelas V SD. Jurnal PGSD, 2 (1), 111.

Novitasari, W. \& Khotimah, N. (2016) Dampak penggunaan gadget terhadap interksi sosial anak usia 56 tahun. Jurnal PAUD Teratai, 05 (03): 182- 186.

Creswell, J. W. (2009) Research design: Qualitative, quantitative, and mixed methods approaches, Canada: SAGE Publications, Incorporated.

Akbar, Sa'dun. (2015). Instrumen Perangkat Pembelajaran. Bandung: PT. Remaja Rosda Karya.

Sari, T. P., \& Mitsalia, A. A. (2016). Pengaruh penggunaan gadget terhadap personal sosial anak usia pra sekolah di TKIT Al Mukmin. Profesi, 13 (2), 72-78.

Warisyah, Yusmi. 2015. "Pentingnya Pendampingan Dialogis Orang Tua Dalam Penggunaan Gadget Pada Anak Usia Dini'. Prosiding. Seminar Nasional Pendidikan di FKIP Universitas Muhammadiyah Ponorogo. Ponorogo, 7 Nopember 2015.

Hurlock, Elizabet. B. 1997. Psikologi Perkembangan. Jakarta: Penerbit Erlangga. 